\section{Recent Developments in British Surveying Instruments}

Brigadier M. N. MacLeod delivered the Thomas Young Oration of the Physical Society on March 24, taking as his subject "Some Recent Developments in British Surveying Instruments". Referring to the aerial camera as a surveying instrument, he pointed out that all parts of the ground must be photographed from two separate points. Plotting is done by combining, stereoscopically or otherwise, two such pictures. Plotting from tilted photographs requires complicated apparatus. In the first plotting machines the air positions of the camera and the direction of its optical axis had to be determined by a "resection in space" from control points on each photograph. There are theoretical as well as practical objections, however, to such independent determinations. In 1926, Dr. Foureade propounded the idea of first determining the relative positions of the air cameras without reference to ground points, and devised a stereo-goniometer for this purpose. This principle has been made the basis of a new British automatic plotting machine constructed for the War Office and about to be delivered to the Ordnance Survey. In the majority of automatic plotters, the photographic picture is reconstructed stereoscopically and the image of a mark in the stereoscope is superimposed optically on the view. The visual or 'floating' mark can be moved about by the plotting mechanism and can be made to coincide in depth as well as in alignment with any point in the view. The apparent movements of the mark are transmitted mechanically to a plotting pencil. In all automatic plotters, however, much time is taken in the preliminary adjustment for reconstructing the stereoscopic view and determining its scale and orientation. It is hoped that the new instrument will enable this preliminary setting to be done decidedly more quickly than is the case in any existing foreign model.

\section{Prehistoric Fire-Dog}

Colonel J. C. Wynne Finch, a governor of the National Museum of Wales, has lent to the Museum for purposes of exhibition for a period of two years the remarkable example of Celtic iron-work known as the Capel Garmon fire-dog, which was found at Carreg Caedog Farm, near Capel Garmon, in 1852 by a labourer when digging a drainage trench. It is described (The Times, March 16) as constructed of two vertical bars, bent over at the top to form a neck, on to which is fastened a crest and the schematized head of an ox. The bars stand on semi-circular arched feet, and are connected by a horizontal bar thickened towards the middle, presumably to support the weight of the logs. The uprights are ornamented on each side by a ribbon of iron, bent in semi-circular loops, and with spiral coils at the top and bottom. The ribbon between the loops is attached to the upright by heavy decorative rivets. Other finds of a generally similar character have been made in south-eastern England in tombs belonging to the Belgic culture of the Iron Age, to be dated circa 100 B.C. - A.D. 50, while others, again approximately of the same period, have been found on the Continent in areas occupied by the Celts, who seem in this instance to have adapted an object of Mediterranean type to their own uses. It is pointed out that the Mediterranean influence may perhaps be seen in a very special fashion in the crest of the Capel Garmon fire-dog, which with its thin vertical strip pierced at intervals with circular holes and bearing a thick bar flattened and curled at its lower end, and in its row of knobs representing the plume socket, suggests a Greek helmet crest. None of the fire-dogs so far discovered is as elaborate as the Capel Garmon specimen, as they lack the crest, the loops on the uprights, and the rivet-heads. The discovery of pairs of fire-dogs together suggests, although it is not known with certainty, that two formed a set, one being placed on each side of the fire, which was laid in the centre of the house.

\section{New Egyptian Royal Tomb at Tanis}

Further details of the Egyptian royal tomb recently discovered at Tanis in the Nile Delta (see Nature, March 25, p. 512) suggest that the results of its examination may prove of even greater interest than was anticipated at first. Another chamber has now been discovered and opened. It also proved to be intact. It is thought that the explorers may be fortunate enough to find still other chambers which have not been plundered; while there is the even more stimulating possibility that this may be the first only of a whole series of royal burials belonging to the twenty-first and twenty-second dynasties. Again, the walls both of the chamber in which the royal sarcophagus has been found and of that since opened are covered with paintings and inscriptions, from which presumably many historical data will be recovered, such as were, strikingly, absent from the tomb of Tutankhamen. Among those in the chamber of the sarcophagus is the cartouche of King Psusenes, identified with the King Shishak, who plundered Jerusalem in the reign of Rehoboam in 930 B.c. Many finely sculptured jars, some with beautifully carved stoppers, much jewellery of gold and precious stones and a huge sculptured human foot have been found. Within the silver mummy case of King Shishak was an inner casing of gold and leather. The first pictures of the tomb, funerary chambers and finds to reach England appeared in The Times of March 27.

\section{Archæological Expeditions to the East}

ThE departure for the East of two archæological expeditions is announced, one proceeding to Iran and Afghanistan, and the other to Aden. Of these the former, conducted by Mr. Arthur Upham Pope, an authority on Sassanian art and archæology, is the first section of a new architectural survey expedition of the American Institute of Iranian Art and Archæology, of which Mr. Pope was one of the founders and the principal promoter. The members of the expedition will be engaged in studies preparatory to a complete history of Iranian architecture, a muchneeded undertaking which, when complete, will contribute materially to the advancement of Iranian 
cultural and historical studies. On the second expedition, Mr. L. P. Kirwan, a well-known archæologist, will visit the Aden Protectorate for the purpose of inspecting and examining a number of archæological sites between Aden and Lahej. He will visit Amadiya on the Audhali Plateau, which will be surveyed, and the ruins of Qohlan in Wadi Beihan. Mr. Kirwan will also examine and report on the archæological material in the Aden Museum, which is now in process of being reorganized.

\section{Exhibition of Chinese Art}

AN exhibition has been arranged in the North Court of the Victoria and Albert Museum, South Kensington, which illustrates comprehensively the whole range of Chinese art from the prehistoric period at about 3000 B.c. down to modern times. With the exception of a small series to be seen in the Department of Ceramics, this exhibition includes all the objects of Chinese art of all kinds now in the possession of the Museum. It includes the Museum's share of the Eumorfopoulos collection, which provides some of the most striking and widely known exhibits. The arrangement of the exhibition is chronological and cultural. Each exhibit is grouped with others, whatever their character or material, whether of jade, textile, painting or pottery, provided they belong to the same period and are of the same cultural origin. The first and earliest exhibit is a neolithic pot of about 3000 B.C. A special feature of the exhibition is the important collection of ritual bronzes, which has been provided with special caselabels incorporating small photographs, illustrating the main features of style. A collection of Buddhist sculpture of the fifth and sixth century A.D. is on loan from Baron von der Heydt. Especially noteworthy are two wooden sculptures, one a figure of Kuan Yin, Goddess of Mercy, dating from the twelfth century, and a statue of a seated man, belonging to the fifteenth century. The exhibition is to be permanently on view.

\section{British Museum (Bloomsbury) : Recent Acquisitions}

Accessions to the collections of antiquities and ethnographical objects in the British Museum (Bloomsbury) of exceptional interest were reported at the meeting of the Trustees on March 11. Of these one is a remarkably fine example of the Irish twisted gold torque, which has been accepted on loan for temporary exhibition from the Duke of Westminster. It is made from a single bar of gold, 50 inches long and weighing $26 \mathrm{oz}$. It has been chiselled and beaten into four flanges and then twisted and bent into a circle. The ends are recurved to fit into one another to form a fastening. It is of a type characteristic of the Middle Bronze Age and dates from about 1200 B.c. It was found in 1816 at Bryn Sion Farm, Flintshire. Another accession to the Department of British Antiquities is a collection of fragments of pots of dark earthenware, freely ornamented towards the top with hatchings, pitting, and finger-nail marks, presented by Mr. J. P. T.
Burchell. They were excavated by him in the Ebbs. fleet Valley, Kent, at a depth of $10 \mathrm{ft}$. in stratigraphical conditions, which make it certain that this pottery is older than the neolithic period as at present understood. It is possible that this may prove to be the oldest pottery as yet found in Britain. It would seem to be connected with mesolithic types found on the Continent, such as those from the Danish kitchenmiddens. It differs from British 'Neolithic A', and may indeed prove to be a predecessor of 'Peterborough' ware. Another accession of considerable archæological interest is a human face, almost circular in outline, carved on a piece of Bath stone found near Charterhouse-on-Mendip. It has almondshaped eyes and a small round hole for a mouth. It dates from the period of Roman occupation; but is thought to represent a native barbaric tradition. Of the ethnographical accessions the most striking is a wooden totenic figure of an eagle made by the Siwash Indians of Vancouver Island. It stands about four feet high, with wings half-spread, and is painted in gaudy colours, and has a fierce human face painted on the breast.

\section{British Museum (Natural History): Recent Acquisitions}

The Mineral Department of the British Museum (Natural History) has acquired through Mr. Arthur Russell a small collection of foreign minerals from the collection of Philip Rashleigh, F.R.S., of Menabilly, near Fowey, Cornwall (1729-1811). The main part of the Rashleigh Collection is in the Truro Museum. Mr. Arthur Champion has collected rocks from various localities on a remarkable motor journey he made in 1937 from Dakar to Nairobi. The collection includes specimens from French West Africa and the Belgian Congo as well as from Senegal, Gold Coast and Nigeria. A fine specimen of the mineral thortveitite has been received from Prof. T. Vogt of Trondhjem, Norway, and suitable specimens have been sent him in exchange.

\section{Broadcasting in 1938}

THE report of the Governors of the British Broadcasting Corporation for the year ended December 31, 1938, as presented to His Majesty's PostmasterGeneral, has recently been published as a white paper (Cmd. 5951. London: H.M. Stationery Office. $6 d$. net). The scope of the report is indicated by the headings of the main sections into which it is divided, namely, programmes, public relations, engineering and administration. During the year under review, the Corporation suffered a loss by the resignations of its first director-general, Sir John Reith, and of the deputy director-general, Vice-Admiral Sir Charles Carpendale. Mr. F. W. Ogilvie was appointed to the first position, while Mr. C. G. Graves became the new deputy director-general. The staff of the B.B.C. is now more than four thousand, and these have provided to nearly nine million licensed listeners a home broadcasting service of some 79,500 hours in 1938, with the remarkably small breakdown time of 0.023 per cent. In addition, nearly 33,000 hours 